\title{
PENGARUH STRATEGI RELATING, EXPERIENCING, APPLYING, COOPERATING, TRANSFERRING (REACT) TERHADAP KEMAMPUAN KONEKSI MATEMATIS SISWA SMP DHARMA BHAKTI PALEMBANG
}

\author{
Defri Pratama ${ }^{1}$, Eva Susanti $^{2}$ \\ ${ }^{1}$ SMA Dharma Bakti Palembang \\ ${ }^{2}$ Program Studi Pendidikan Matematika, Universitas Tamansiswa Palembang \\ defri.pratama1991.dp@gmai.com
}

\begin{abstract}
The aims of this research was seeing the effect of learning with the Relating, Experiencing, Applying, Cooperating, and Transfering (REACT) strategies on the mathematical connection ability of students at the Dharma Bhakti High School Palembang in the 2016/2017 school year. This research was conducted in three stages, namely the observation and planning stage, the implementation phase and the evaluation and reporting stage. Based on the results of indicators of students 'mathematical abilities obtained data analysis results from the results of mathematical connection tests of students' prism subjects in the experimental class and the control class. In the final test the average for the experimental class was better than the control class, namely 79.2 and 64.5. So it was concluded that there was an influence of the learning strategies of Relating, Experiencing, Applying, Cooperating, Transfering (REACT) on the mathematical connection ability of the Dharma Bhakti High School students in Palembang.
\end{abstract}

Key Words: REACT Strategy, Mathematical Connection

Abstrak: Penelitian ini dilaksanakan dengan tujuan untuk melihat pengaruh pembelajaran dengan strategi Relating, Experiencing, Applying, Cooperating, Transferring (REACT) terhadap kemampuan koneksi matematis siswa di SMP Dharma Bhakti Palembang pada tahun ajaran 2016/2017. Penelitian ini dilakukan dengan tiga tahapan, yaitu tahap observasi dan perencanan, tahap pelaksanaan dan tahap evaluasi serta pelaporan. Berdasarkan hasil indikator kemampuan matematis siswa diperoleh hasil analisis data hasil tes koneksi matematis siswa materi pokok prisma pada kelas eksperimen maupun kelas kontrol. Pada tes akhir rata-rata untuk kelas eksperimen lebih baik daripada kelas kontrol, yaitu 79,2 dan 64,5. Sehingga disimpulkan ada pengaruh strategi pembelajaran Relating, Experiencing, Applying, Cooperating, Transferring (REACT) terhadap kemampuan koneksi matematis siswa SMP Dharma Bhakti Palembang.

Kata Kunci: Strategi REACT, Koneksi Matematis

\section{PENDAHULUAN}

Kemampuan koneksi matematis merupakan kemampuan membuat hubungan antara matematika dengan kehidupan sehari-hari. Menurut Suherman (2010) kemampuan koneksi dalam matematika adalah kemampuan untuk mengaitkan konsep atau aturan matematika yang satu dengan yang lainnya, dengan bidang studi lain atau dengan aplikasi pada kehidupan nyata. Siswa akan memahami setiap materi 
dengan baik dan lebih mendalam jika siswa telah mampu melakukan koneksi antara beberapa konsep matematis.

Kemampuan

koneksi

merupakan salah satu kemampuan matematis yang ditetapkan oleh National Council of Teachers of Mathematics (NCTM). NCTM (2000) menetapkan lima standar kemampuan matematika siswa, yaitu kemampuan koneksi (connection), kemampuan komunikasi (communication), kemampuan pemecahan masalah (problem solving), kemampuan penalaran (reasoning) dan kemampuan representasi (representation). Kemampuan koneksi juga terdapat pada tujuan pembelajaran matematika kurikulum 2006, yaitu meliputi (1) koneksi antar konsep dalam matematika dan penggunannya dalam pemecahan masalah, (2) pemecahan masalah, (3) komunikasi dan representasi, (4) penalaran, dan (5) faktor afektif (Depdiknas, 2006). Dengan demikian kemampuan koneksi merupakan salah satu standar yang harus dimiliki oleh siswa agar mereka mampu mengaplikasikan dan menerapkan tujuan pembelajaran matematika didalam kehidupan seharihari.

Namun berdasarkan hasil survey Programme for International Student Assessment (PISA) 2012, pada ajang tersebut Indonesia berada di peringkat 64 dari 65 negara peserta. Skor rata-rata yang diperoleh Indonesia adalah 375, jauh dibawah rata-rata OECD (Organisation for Economic Cooperation and Development) yakni 494. Hasil PISA pada aspek topik geometri menunjukkan bahwa siswa Indonesia lemah khususnya dalam pemahaman ruang dan bentuk (Untung, 2008:1). Hal ini menunjukkan bahwa siswa Indonesia lemah dalam kemampuan berpikir tingkat tinggi dimana kemampuan koneksi matematis merupakan salah satu kemampuan berfikir tingkat tinggi.

Siswa kelas VIII SMP Dharma Bhakti Palembang, pada tahun ajaran 2015/2016 mengalami kesulitan dalam kemampuan berfikir tingkat tinggi pada materi bangun ruang sisi datar Prisma. Hal ini dapat dilihat dari rendahnya nilai siswa pada saat latihan dan ulangan harian pada materi Prisma. Nilai yang mereka dapatkan umumnya masih dibawah rata-rata dan Kriteria Ketuntasan Minimal.

Dari hal di atas untuk menumbuhkan kemampuan koneksi matematis siswa, peneliti memilih salah satu alternatif strategi pembelajaran yang dikemukakan oleh CORD (Marthen, 2010), yaitu Strategi REACT. REACT merupakan akronim dari salah satu strategi pembelajaran dengan lima aspek yang merupakan satu kesatuan, yaitu relating adalah strategi dengan mengajak siswa mengaitkan materi yang dipelajari dengan sesuatu yang tidak asing lagi bagi siswa. Experiencing adalah strategi dengan menginstruksikan siswa melakukan pencarian dan penyelidikan yang dilakukan secara aktif untuk menemukan makna konsep yang dipelajari. Applying adalah strategi dengan melakukan penerapan pengertian dankonsep matematika dalam menyelesaikan masalah. 
Cooperating adalah strategi dengan memberikan kesempatan kepada siswa untuk belajar secara bekerja sama dan saling berbagi. Kemudian Transfering adalah strategi yang memberikan keluwesan kepada siswa dengan pengetahuan matematika dalam penyelesaian masalah matematika maupun di luar matematika.

Langkah-langkah pembelajaran dengan strategi REACT berdasarkan penelitian yang dilakukan Sayuthi (2010) dapat meningkatkan kemampuan siswa dimana pada tahap awal relating guru memberikan soal yang mengaitkan antara materi yang akan dipelajari demgam contoh dalam kehidupan sehari-hari. Tahap experiencing merupakan pembelajaran yang membuat siswa belajar dengan melakukan kegiatan matematika melalui eksplorasi, penemuan, dan pencarian menjadi pengalaman untuk mereka. Tahap applying adalah belajar dengan menerapkan konsep-konsep yang telah dipelajari untuk digunakan dengan memberikan latihan-latihan yang relevan dan realistik. Tahap cooperating adalah pembelajaran dengan guru mengkondisikan siswa agar bekerja sama dan menciptakan kondisi agar dapat saling berbagi pendapat, merespon dan berkomunikasi dengan yang lainnya. Kemudian pada tahap transferring adalah pembelajaran yang membuat siswa belajar menggunakan pengetahuan yang telah mereka pelajari dalam konteks atau situasi baru yang belum dipelajari, dan pada tahap penutup guru membimbing siswa untuk membuat intisari kesimpulan dan evaluasi.

Dengan strategi REACT ini menjadikan siswa akan selalu terlibat secara terus menerus berfikir dan mengetahui hubungan koneksi antar konsep, baik sesama konsep matematika maupun dengan bidang lain yang hanya sekedar dilakukan dengan cara membaca dan menghafal secara berulang-ulang serta mendengarkan ceramah guru. Dalam hal inilah guru hendaknya menanamkan kepada siswa rasa minat, kepercayaan dan butuh akan pemahaman hubungan tersebut.

Berdasarkan hal di atas maka peneliti fokus pada strategi REACT untuk melihat pengaruh kemampuan koneksi matematis pada siswa. Oleh karena itu, penulis menetapkan penelitian ini dengan judul "Pengaruh Strategi Relating, Experiencing, Applying, Cooperating, Transferring (REACT) terhadap kemampuan koneksi matematis Siswa SMP Dharma Bhakti Palembang"

Berdasarkan latar belakang di atas maka rumusan masalah dari peneliti adalah "Apakah ada pengaruh strategi Relating, Experiencing, Applying, Cooperating, Transferring (REACT) terhadap kemampuan koneksi matematis siswa SMP Dharma Bhakti Palembang?"

\section{TINJAUAN TEORETIS}

Strategi pembelajaran merupakan cara yang dilakukan untuk komunikasi 2 arah, sebagai pendidik mengajar dan belajar dilakukan oleh peserta didik. Menurut Suprijono 


\section{(2014:83) strategi pembelajaran} merupakan kegiatan yang dilakukan dan dipilih untuk memberikan bantuan dan fasilitas ke peserta didik untuk mencapai tujuan dari pembelajaran.

Dari penjelasan di atas maka dapat disimpulkan bahwa strategi pembelajaran adalah sebagai acuan perencanaan yang memuat dan menerangkan tentang rangkaianrangkaian kegiatan yang didesain untuk mencapai tujuan dari pembelajaran tersebut.

\section{Strategi REACT}

\section{CORD}

(Marthen, 2010)

menjelaskan bahwa REACT merupakan akronim

dari sebuah strategi pembelajaran kontekstual dengan lima aspek yang merupakan satu kesatuan yaitu mengaitkan (relating), melakukan pencarian dan penyelidikan yang dilakukan oleh siswa secara aktif untuk menemukan makna konsep yang dipelajari (experiencing), penerapan pengertian dan konsep matematika dalam penyelesaian masalah (applying), memberikan kesempatan kepada siswa untuk belajar secara bekerja sama dan berbagi (cooperating), dan memberikan kepada siswa pengetahuan matematika dalam penyelesaian masalah matematika maupun di luar matematika (transfering). Adapun menurut CORD (1999) penjelasannya sebagai berikut:

a. Relating, yaitu belajar dalam konteks mengaitkan apa yang hendak dipelajari dengan pengalaman kehidupan sehari-hari.

b.Experiencing, yaitu belajar dalam konteks eksplorasi, mencari, dan menemukan sendiri.

c.Applying, yaitu belajar dengan mengaplikasikan konsep dan informasi yang dimiliki siswa dalam konteks yang akan dipelajari sehingga menjadi suatu konsep atau keterampilan ke masa depan.

d. Cooperating, yaitu proses belajar dimana siswa belajar berbagi (sharing) dan berkomunikasi dengan siswa lain, teman sekolompok atau sekelas,antar siswa belajar dengan salingtukar pendapat (sharing), dan saling merespon satu sama lain.

e. Transferring, yaitu siswa belajar menggunakan apa yang telah dipelajari untuk menyelesaikan persoalan baru yang akan dihadapi.

Pada dasarnya strategi REACT memuat lima tahapan yang saling berkesinambungan dan kontinu. Hal ini dapat dilihat dari tabel 1 langkahlangkah Strategi REACT.

Tabel 1

Langkah-langkah Strategi REACT

\begin{tabular}{lll}
\hline \multicolumn{1}{c}{ REACT } & \multicolumn{1}{c}{ Pendidik/Guru } & \multicolumn{1}{c}{ Peserta didik/Siswa } \\
\hline Relating & Guru menentukan bahan ajar, & Siswa mengaitkan materi baru \\
(mengaitkan / & kemudian menganalisis bahan & dengan materi lama yang sudah \\
menghubungkan) & ajar dilanjutkan mencari & dikuasainya. Mengaitkan materi \\
& konteks tersebut. Kemudian & belajar dengan konteks \\
& menyusun kegiatan yang & pengalaman kehidupan nyata \\
& memungkinkan siswa untuk & karena belajar bukanlah \\
& melakukan aktivitas relating & menghafal.
\end{tabular}




\begin{tabular}{|c|c|c|}
\hline & $\begin{array}{l}\text { (mengaitkan/menghubungkan) } \\
\text { bahan ajar dengan konteks }\end{array}$ & \\
\hline $\begin{array}{l}\text { Experiencing } \\
\text { (mengalami) }\end{array}$ & $\begin{array}{l}\text { Guru mengajak siswa } \\
\text { beraktivitas mengeksplorasi, } \\
\text { menemukan/ menciptakan } \\
\text { sesuatu yang berkaitan dengan } \\
\text { bahan ajar yang sedang } \\
\text { dipelajarinya. }\end{array}$ & $\begin{array}{l}\text { Siswa mengeksplorasi materi dari } \\
\text { konteks yang ada, menemukan } \\
\text { dan memahami sendiri materi } \\
\text { yang sedang dipelajarinya. }\end{array}$ \\
\hline $\begin{array}{l}\text { Applying } \\
\text { (menerapkan) }\end{array}$ & $\begin{array}{l}\text { Guru membimbing siswa untuk } \\
\text { menerapkan prinsip-prinsip } \\
\text { yang telah dipelajari siswa }\end{array}$ & $\begin{array}{l}\text { Siswa mempraktikkan/ } \\
\text { menerapkan hasil dari } \\
\text { pemahamannya terhadap materi } \\
\text { dari konteks yang } \\
\text { menghubungkan dari kehidupan } \\
\text { sehari-hari. }\end{array}$ \\
\hline $\begin{array}{l}\text { Cooperating } \\
\text { (bekerja sama) }\end{array}$ & $\begin{array}{l}\text { Guru membimbing siswa } \\
\text { dalam membentuk kelompok } \\
\text { belajar dikelas }\end{array}$ & $\begin{array}{l}\text { Siswa belajar dalam bentuk } \\
\text { kelompok. Disini siswa bekerja } \\
\text { sama dan berkomunikasi dalam } \\
\text { menyelesaikan masalah yang ada } \\
\text { antar kelompok. Hal ini } \\
\text { memudahkan siswa mencapai } \\
\text { kemampuan potensialnya. }\end{array}$ \\
\hline $\begin{array}{l}\text { Transferring } \\
\text { (mentransfer) }\end{array}$ & $\begin{array}{l}\text { Guru menyediakan tugas baru } \\
\text { untuk dikerjakan di kelas }\end{array}$ & $\begin{array}{l}\text { Siswa mengerjakan tugas baru } \\
\text { sebagai tanda bahwa siswa dapat } \\
\text { menerapkan materi yang telah } \\
\text { dipelajari untuk memecahkan } \\
\text { masalah baru. }\end{array}$ \\
\hline
\end{tabular}

Sumber : Sutawidjaja dan Afgani (2011:5.42-5.47)

Kemampuan Koneksi Matematis

Koneksi berasal dari kata connection dalam bahasa inggris yang diartikan hubungan. Koneksi secara umum adalah suatu hubungan atau keterkaitan. Keterkaitan atau hubungan dengan matematika disebut koneksi matematika.

Menurut Sumarmo

koneksi matematika dapat diartikan sebagai keterkaitan secara internal dan eksternal. Keterkaitan secara internal adalah keterkaitan antara konsepkonsep matematika itu sendiri sedangkan keterkaitan secara eksternal adalah keterkaitan antara matematika dengan kehidupan sehari-hari.
Menurut Suherman (2010), kemampuan koneksi dalam matematika adalah kemampuan untuk mengaitkan konsep atau aturan matematika yang satu dengan yang lainnya, dengan bidang studi lain atau dengan aplikasi pada kehidupan nyata. Siswa akan memahami setiap materi dengan baik dan lebih mendalam jika siswa telah mampu melakukan koneksi antara beberapa konsep matematis. Mudah sekali mempelajari matematika kalau kita melihat penerapannya di dunia nyata (Johnson, 2010)

Dari pendapat di atas bahwa kemampuan koneksi matematis merupakan upaya yang dilakukan siswa 
dalam mengaitkan konsep matematika dengan matematika, matematika dengan bidang ilmu lain, dan mengaitkan serta menggunakan dalam kehidupan sehari-hari.

\section{Indikator Koneksi Matematis}

Menurut NCTM (National

Council of Teacher of Mathematics) (2000:64) indikator untuk kemampuan koneksi matematika yaitu Mengenali dan memanfaatkan hubunganhubungan antara gagasan dalam matematika, Memahami bagaimana gagasan-gagasan dalam matematika saling berhubungan dan mendasari satu sama lain untuk menghasilkan suatu keutuhan koheren Mengenali dan menerapkan matematika dalam konteks diluar matematika

Secara umum terdapat tiga aspek kemampuan koneksi matematika, yaitu

1. Menuliskan masalah kehidupan sehari-hari dalam bentuk model matematika. Pada aspek ini, siswa diharapkan mampu untuk mengkoneksikan antara masalah pada kehidupan sehari-hari dan matematika

2. Menuliskan konsep matematika yang mendasari jawaban. Pada aspek ini, siswa diharapkan mampu menuliskan konsep matematika yang mendasari jawaban guna memahami keterkaitan antar konsep matematika yang akan digunakan

3. Menuliskan hubungan antar obyek dan konsep matematika. Pada aspek ini, siswa diharapkan mampu untuk menuliskan hubungan antar konsep matematika yang digunakan dalam menjawab soal yang diberikan

Berdasarkan aspek dan indikator dari koneksi diatas maka kemampuan koneksi matematis siswa yang akan diteliti dalam penelitian ini dapat dilihat dari indikator-indikator berikut :

1. Mengenali representasi equivalen dari konsep yang sama

2. Mengenali hubungan prosedur matematika suatu representasi yang equivalen

3. Menggunakan dan menilai keterkaitan antar topik matematika dan keterkaitan diluar matematika

4. Menggunakan matematika dalam kehidupan sehari-hari

\section{Hubungan Antara Strategi REACT dengan Kemampuan Koneksi Matematis}

Hubungan antara strategi REACT yang memiliki lima tahapan yang mana semuanya dialami oleh siswa dalam pembelajaran dan kemampuan koneksi yang berupa mencari dan mengaitkan (relating) antar konsep matematika (indikator pertama). Dengan mengalami (experiencing), bekerja sama (cooperating) sendiri maka siswa akan memahami kalau apa yang dipelajari akan membantu dalam mengerjakan dan mengatasi permasalahan yang akan dihadapi (indikator kedua dan ketiga).Kemudianmenerapkan atau menggunakan (applying) serta mentransfer (transferring) pengetahuan yang diperoleh ke dalam kehidupan sehari-hari baik untuk menyelesaikan persoalan atau permasalahan yang 
dihadapi di kehidupan sehari - hari (indikator keempat). Untuk mencapai keempat indikator tersebut maka seorang guru tentunya harus memiliki sikap yang cekatan dan terampil dalam mendorong dan membantu siswa dalam mencari, menemukan, memahami, mengetahui dan menerapkannya sehingga strategi REACTsecara tidak langsung akan melatih dan meningkatkan kemampuan koneksi matematis siswa untuk selalu berkembang.

\section{METODOLOGI PENELITIAN}

Metode yang digunakan dalam penelitian ini adalah metode True Experimental Designyaitu jenis-jenis eksperimen yang dianggap sudah baik karena sudah memenuhi persyaratan yang mana adanya kelompok lain yang tidak dikenal eksperimen dan ikut mendapatkan pengamatan. Dengan adanya kelompok pembanding atau kelompok kontrol ini akibat yang diperoleh dari perlakuan dapat diketahui secara pasti karena dibandingkan dengan yang tidak mendapat perlakuan (Arikunto, 2006:79). Dalam hal ini peneliti akan menggunakan Posttest - Only Control Design. subjek penelitian adalah seluruh siswa kelas VIII di SMP
Dharma Bhakti Palembang semester genap tahun pelajaran 2016/2017.

Teknik pengumpulan data pada penelitian ini adalah tes dan dokumentasi. Tes yang dilakukan untuk mengetahui hasil kemampuan koneksi matematis siswa setelah mendapat perlakuan khusus (pada kelompok kelas eksperimen). Tes yang akan digunakan adalah tes berupa uraian. Adapun dokumentasi yang dikumpulkan dalam penelitian yang akan dilakukan adalah lembar jawaban siswa dan foto selama kegiatan berlangsung.

\section{HASIL DAN PEMBAHASAN}

Hasil data penelitian ini adalah skor kemampuan koneksi matematis siswa yang diperoleh dari hasil latihan dan tes akhir baik kelas eksperimen maupun kelas kontrol pada materi; 1) unsur-unsur, jenis, dan jaring prisma, 2) luas permukaan prisma, 3) volume prisma. Setelah diberikan pembelajaran dengan strategi REACT pada kelas VIII C selaku kelas eskperimen yang terdiri dari 35 siswa dan hasil tes pada kelas kontrol VIII B yang terdiri dari 35 siswa yang mendapatkan pengajaran dengan strategi konvensional atau ekspositori. Berikut hasil data tes kemampuan koneksi matematis siswa.

Tabel 2

Analisis Data Tes Kemampuan Koneksi Matematis Siswa

\begin{tabular}{cc}
\hline Kelas Eksperimen & Kelas Kontrol \\
\hline Rata-rata $(\overline{\boldsymbol{x}})=79,2$ & Rata-rata $(\bar{x})=64,5$ \\
Varians $\left(\mathrm{s}^{2}\right)=142,865$ & Varians $\left(\mathrm{s}^{2}\right)=137,707$ \\
Simpangan Baku $(\mathrm{s})=11,95$ & Simpangan Baku $(\mathrm{s})=11,73$ \\
\hline
\end{tabular}


Tabel 3

Uji Normalitas Data Kemampuan Koneksi Matematis Siswa

\begin{tabular}{cccc}
\hline Kelas & $X_{\text {hitung }}$ & $X_{\text {tabel }}$ & Kriteria \\
\hline Ekperimen & 6,650 & 11,07 & Berdistribusi Normal \\
Kontrol & 8,115 & 9,488 & Berdistribusi Normal \\
\hline
\end{tabular}

Dari tabel di atas terlihat bahwa matematis siswa baik kelas eksperimen $\mathrm{X}^{2}$ hitung $<\mathrm{X}_{\text {tabel }}^{2}$ untuk kelas eksperimen dan kelas kontrol berdistribusi normal. dan kelas kontrol. Maka untuk uji Maka dilakukan uji homogenitas. normalitas data kemampuan koneksi Hasilnya sebagai berikut:

Tabel 4

Hasil Perhitungan Uji Homogenitas

\begin{tabular}{ccccc}
\hline Kelas & $\mathrm{S}^{2}$ & $\mathrm{~F}_{\text {hitung }}$ & $\mathrm{F}_{\text {tabel }}$ & Kriteria \\
\hline Eksperimen & 142,865 & 1,0374 & 1,854 & Homogen \\
Kontrol & 137,707 & & & \\
\hline
\end{tabular}

Uji homogenitas soal tes akhir antara kelas eksperimen dan kelas kontrol memperoleh $\mathrm{F}_{\text {hitung }}=1,037$ dan $\mathrm{F}_{\text {tabel }}=1,854$. Karena $\mathrm{F}_{\text {hitung }}<\mathrm{F}_{\text {tabel }}$ maka dapat disimpulkan kedua data mempunyai varians yang sama atau datanya homogen.

Setelah pembelajaran di kelas eksperimen dan kelas kontrol ini:

Tabel 5

Hasil Perhitungan Uji-t (Uji Hipotesis)

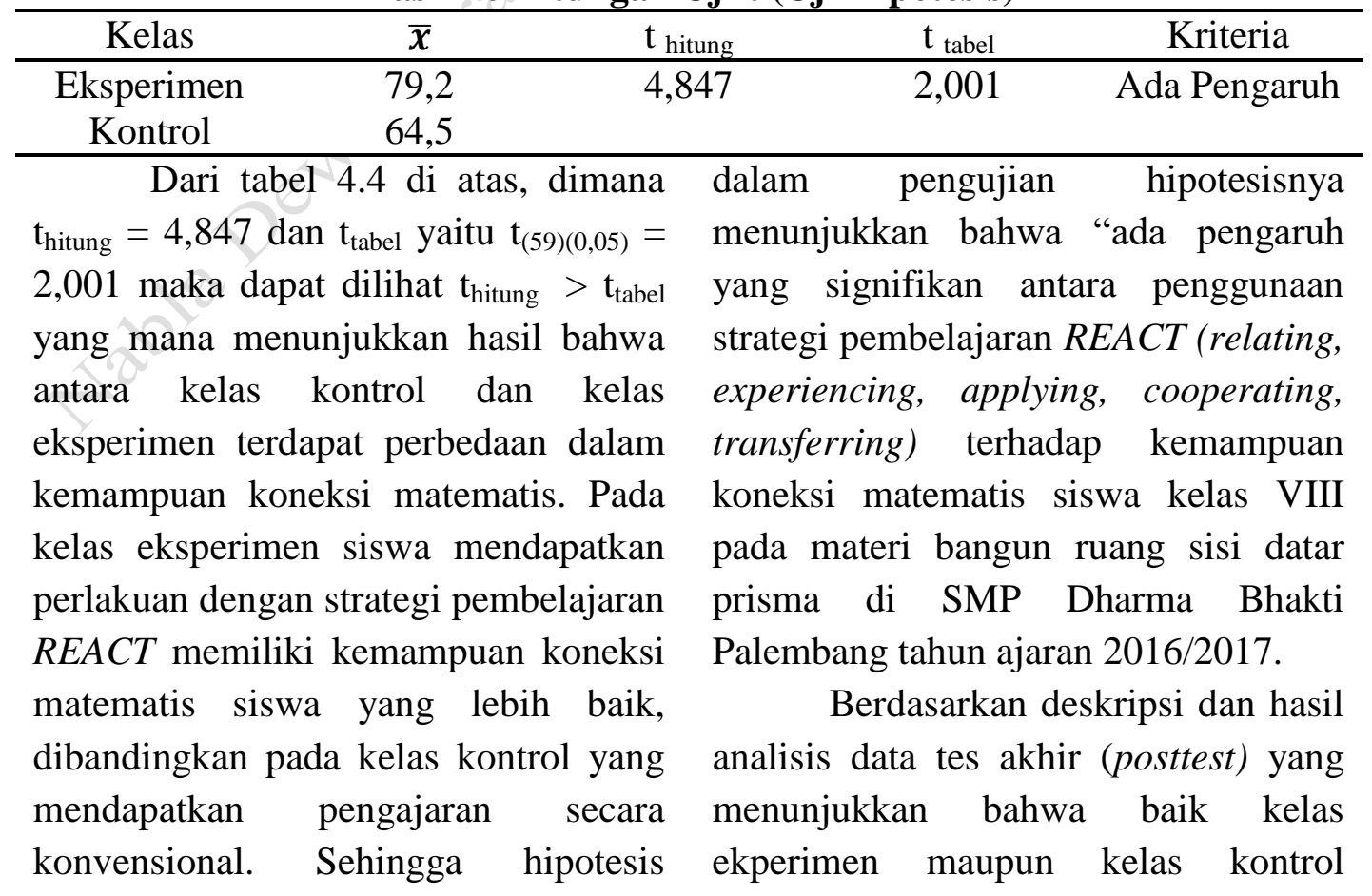


keduanya berdistribusi normal dan homogen atau tidak ada perbedaan varians yang signifikan sehingga dapat dilakukan pengujian uji $\mathrm{t}$ (uji hipotesis). Dari hasil data diatas maka dapat dinyatakan bahwa strategi REACT (Relating, Experiencing, Applying, Cooperating, Transferring) dapat memberikan pengaruh terhadap kemampuan koneksi matematis siswa. Hal ini dapat diketahui dari hasil ratarata kemampuan koneksi matematis siswa pada tes akhir (posttest), pada kelas eksperimen lebih baik daripada kelas kontrol. Dimana rata-rata kelas eksperimen yaitu 79,2 dan kelas kontrol yaitu 64,5.

Dilihat dari hasil rata-rata kemampuan koneksi matematis siswa, siswa yang mendapat pembelajaran dengan strategi REACT ini lebih baik dalam memahami materi bangun ruang sisi datar prisma daripada kelas kontrol yang mendapatkan pembelajaran secara konvensional. Hal ini sejalan dengan penelitian para peneliti terdahulu yang melakukan penelitian untuk mengukur kemampuan koneksi matematis siswa.

\section{SIMPULAN DAN SARAN}

Berdasarkan hasil analisis data penelitian dan pembahasan dari penelitian ini, maka kesimpulan dari penelitian ini adalah ada pengaruh strategi pembelajaran Relating, Experiencing, Applying, Cooperating, Transferring (REACT) terhadap kemampuan koneksi matematis siswa SMP Dharma Bhakti Palembang.

\section{DAFTAR PUSTAKA}

Arikunto, Suharsimi. 2006. Prosedur Penelitian Suatu Pendekatan Praktek. Jakarta: Rineka Cipta.

Arikunto, Suharsimi. 2006. Dasar dasar Evaluasi Pendidikan Pendidikan. Jakarta : Bumi Aksara.

CORD. (1999). Teaching mathematics contextually. [online]. Tersedia : http://www.cord.org/uploadesfile s/teaching math_contextually. pdf [9 oktober2011]

Marthen, T. (2010). Pembelajaran Melalui pendekatan REACT meningkatkan kemampuan matematis siswa SMP. Jurnal Pendidikan Indonesia.

NCTM.2000.Principles and standars for school mathematics.Reston, Virginia [ONLINE]. Tersedia : www.nctm.org [10 April 2011]

Sayuthi.2010. Pembelajaran dengan strategi REACT Pada Materi Pertidaksamaan Sebagai Suatu Upaya untuk meningkatkan kemampuan Berfikir Kreatif Siswa Kelas X MAN Malang I. Tesis Jurusan Pendidikan Matematika, Program Pascasarjana Universitas Negeri Malang (tidak dipublikasikan)

Suherman, Eman.2010. Belajar dan pembelajaran matematika. Bandung : UPI.

Sumarmo, Utari.2003. Daya dan Disposisi

Matematik:Apa,Mengapa dan Bagaimana Dikembangkan pada Siswa Sekolah Dasar dan Menengah. Jurusan Matematika ITB: Jurnal Matematika, digilib.uinsbyac.id

Suprijono, Agus.2014. Cooperatif Learning Teori \& Aplikasi PAIKEM.Surabaya:Pustaka Pelajar. 